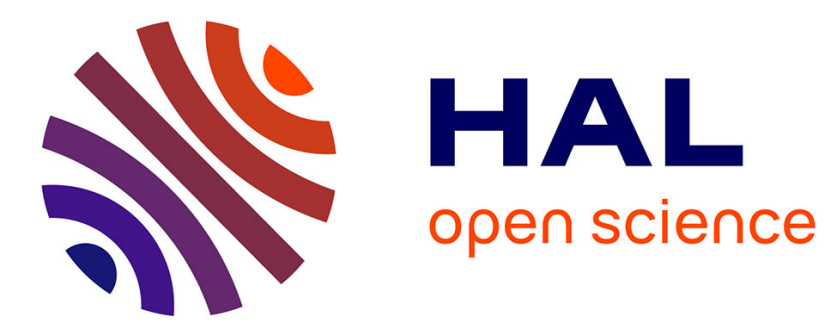

\title{
Legitimizing farmers' new knowledge, learning and practices through communicative action: Application of an agro-environmental policy
}

\author{
Jean-Pierre del Corso, Charilaos Kephaliacos, Gaël Plumecocq
}

\section{To cite this version:}

Jean-Pierre del Corso, Charilaos Kephaliacos, Gaël Plumecocq. Legitimizing farmers' new knowledge, learning and practices through communicative action: Application of an agro-environmental policy. Ecological Economics, 2015, 117, pp.86-96. 10.1016/j.ecolecon.2015.05.017 . hal-01286845

\section{HAL Id: hal-01286845 \\ https://hal.science/hal-01286845}

Submitted on 11 Mar 2016

HAL is a multi-disciplinary open access archive for the deposit and dissemination of scientific research documents, whether they are published or not. The documents may come from teaching and research institutions in France or abroad, or from public or private research centers.
L'archive ouverte pluridisciplinaire HAL, est destinée au dépôt et à la diffusion de documents scientifiques de niveau recherche, publiés ou non, émanant des établissements d'enseignement et de recherche français ou étrangers, des laboratoires publics ou privés. 


\title{
Legitimizing Farmers' New Knowledge, Learning and Practices through Communicative Action: Application of an Agro-Environmental Policy
}

\author{
Jean-Pierre Del Corso \\ National Institute of Agronomy of Toulouse (ENFA) \\ University of Toulouse 1 - LEREPS \\ CharilaosKephaliacos \\ National Institute of Agronomy of Toulouse (ENFA \\ University of Toulouse 1 - LEREPS
}

\section{Gaël Plumecocq (corresponding author)}

INRA, UMR AGIR, Chemin de Borde Rouge - Auzeville, 31326 Castanet-Tolosan France

Gael.Plumecocq@ toulouse.inra.fr

This article examines the role of communication in the process that guides economic actors to integrate the moral obligations implied by adopting sustainability principles in their action choices and to reexamine their practices. We analyze two approaches to implementing agroenvironmental measures that encourage farmers to preserve water resources. Verbal interactions between farmers and agricultural advisors, who are part of these policy programs, are analyzed drawing on Jürgen Habermas's theory of communicative action. The discourse analysis used here shows that communicative action encouraged participants to re-examine the validity of the technical, experiential, and normative knowledge that legitimized their reasons for acting. This study brings to light the fact that, in the context of a business primarily oriented towards making a profit, committing to sustainable development does not only operate in technical terms; such a commitment also requires collective validation of the effectiveness of alternative farming practices.

\section{Highlights:}

- We examine the different strategies of agricultural advice used by two French farmers' cooperatives

- We use lexicometry to analyze how knowledge is disseminated through communicative action

- Personalized advice was more effective in changing practices than advice by territorial sector

- Agronomic innovations were adopted when supported by a normative commitment

- Changing agricultural practices requires redefining the way the farming profession is conceptualized

Keywords: agricultural advice; communicative action theory; agricultural innovations; learning processes; agro-environmental policy 


\section{Introduction}

Society's expectations of agriculture have progressively changed in nature, and the criteria used for evaluating farming have tended to be redefined. For society, farmers are no longer expected to simply satisfy the food needs of a growing population; increasingly, they are also asked to contribute to producing and reproducing environmental goods and services such as maintaining biodiversity (both flora and fauna), providing landscape amenities, and preserving water and soil quality (OECD, 2013, p. 473). Within the European Union, this trend has resulted in changes to public agricultural policies. The 'greening' of the Common Agricultural Policy is now on the agenda (European Commission, 2013). The stated goal is to promote agricultural production systems that are more diversified, self-sufficient in terms of energy, better adapted to local contexts, and that better preserve natural resources. If these proposals are adopted, they will not be able to reconcile agriculture and ecology without first, a profound reorganization of the ways in which the farming profession is conceptualized (Rémy et al., 2006), and, second, without an equally profound transformation in the normative frameworks on which these conceptions are based. In particular, establishing a new model of sustainable farming based on the ecological modernization of agriculture (Horlings and Marsden, 2011) depends on the ability and motivation of actors (especially farmers and farming advisors) to question the validity of the technical knowledge they inherited from the post-war model of intensive farming. ${ }^{1}$ Establishing a new model also presupposes that farmers agree to include society's new environmental concerns in their action choices (Koohafkan et al., 2012), by adopting behavior norms that take into account the environmental interests and values of other actors.

Understanding the ways in which preferences and behavior may be influenced by moral considerations requires a significant conceptual and methodological transformation. We therefore need a better understanding of how collective moral values and individual interests come together, confront each other, or hybridize to give rise to new regimes of decision-making (Norgaard, 2004; Douguet et al., 2007). In economics, some authors (Norgaard, 2007; Zografos et al. 2008) argue that such an understanding requires taking into account the role of deliberation in updating actors' preferences and reasons for acting. Deliberation is viewed as a process of discussion, through which participants compare and contrast their points of view and arbitrate between multiple competing values (Howarth and Wilson, 2006). Values and preferences are considered to be the result of a social construction resulting from interactive debate. For Lo et al. (2013), since deliberation involves reasoning at the group level, it therefore serves as an essential foundation for collective decisionmaking. Deliberation has the virtue of helping 'moralize' preferences, because it encourages each participant to engage in collective reflection about a common good (Wilson and Howarth, 2002). Through the deliberative process, the search for collective interests or the common good takes precedence over individual interests. These studies, and others (O'Hara, 1996; Meppem and Bourke, 1999; Howarth and Wilson, 2006; Spash, 2008; Dietz et al., 2009; Vatn, 2009; Lo, 2013), pay particular attention to discursive exchanges between the parties involved in deliberation, since group deliberation cannot be understood without analyzing the language through which it occurs. Thus, they highlight the usefulness of Habermas' (1981) theory of communicative action for understanding how the mechanism of discussion may facilitate the actors' adoption of a moral stance.

\footnotetext{
${ }^{1}$ Such as the massive use of chemical inputs, destroying hedgerows and earthbanks, filling in ditches, and regularly turning the soil.
} 
We also draw on this Habermassian model to explore the potential of the communicative process to change individual preferences and to help actors move beyond purely individual interests. To do so, we examined the implementation of an environmental incentive program (an Agro-Environmental Measure, hereafter AEM) in two areas of the Midi-Pyrenees Region of France. These measures, created in the European Union starting in 1992, are voluntary, contractual programs designed to encourage farmers to preserve natural resources such as water by paying them for this environmental service. Our analysis focuses on discussions between farmers having voluntarily signed the AEM contract and the farming advisors who supported them during the contract's term (5 years). Our primary goal was to study the ways in which discussion and interaction among the actors influenced their adoption of new forms of agronomic and economic reasoning that better preserved water quality.

This article presents two new contributions to the field of deliberative economics:

- First, in contrast to the majority of studies cited, this paper examines debate between actors from the business world. Rather than analyzing interactions within a public forum bringing together a variety of citizens, we focus on a professional community (farmers, farming advisors, farming cooperatives). In the communicative process studied here, the moral question is inextricably linked to maintaining the economic viability of the business. In this way, we were able to test the hypothesis that integrating new moral values into a business' action choices is facilitated when the actors feel that such integration does not compromise the economic performance of the production system.

- Second, our research method, based on semi-structured interviews, analyses a communicative process that is not based on a face-to-face exchange. Drawing on Bakhtin's dialogic concept of language (1986), we consider that any discourse, even if it is not spoken in a face-to-face interaction, is always a reaction-response to the discourses of others (agreeing or disagreeing). As such, it is necessarily an integral part of an uninterrupted communication process (Voloshinov, 1986). Utterances such as "I was discussing this issue with X," or reported speech, such as "When you hear that... (followed by reported words)," clearly show that the people involved are thinking and speaking within the framework of a dialogic relationship to others, and not in the isolated manner of a sole individual (even though this fact is not necessarily explicitly stated by the actors)."In adopting Bakhtin's perspective, we view the utterances in the discourses of people interviewed as units that constitute a delayed-response communication.

The article has three sections. Section 1 presents the conceptual framework used for analyzing the deliberative processes among economic actors, primarily based on Habermas' communicative action theory (Habermas, 1981, 1983). The second section presents the two empirical cases studied. We describe in detail the methodology used to understand the deliberation among actors that was generated by the AEM program's implementation. This method is based on lexicometric analyses (Reinert, 1983; Lebart et al., 1994) applied to the discourses of farmers and advisors collected during semi-structured interviews. The results of this textual analysis are described in the third section. These results enable us to asses the influence of intercommunication on (i) constructing alternative farming practices and new ways of organizing farmers' work with fewer chemicals, (ii) changing the norms and values 
underlying farming practices, and (iii) adopting a way of thinking that takes into account the concerns of other users of natural resources (here, water).

\section{Communication as a Process of Moral Commitment to Collective Action in Transitioning towards Sustainable Agriculture}

This section begins by describing the particular issues of interactive discussion that are involved in a business's moral commitment, here a farming business. Then, drawing on Habermas' theory of communicative action (1981), we uncover the deeper mechanisms at work in deliberation. In particular, we delineate the ways in which communicative praxis may contribute to changing farmers' preferences. Finally, Bakhtin's theories (1986) are used to explain our study of delayed-response communication.

\subsection{Deliberation and Moral Commitments in Farm Businesses}

Authors such as O'Neil and Spash, (2000), Vatn (2009), and Hodgson (2012) underscore the eminently moral dimension of choices regarding the natural environment. This moral aspect is explained by the fact that many natural resources are common goods, that a plurality of environmental values exist, and that these have weaker or stronger incommensurability (O’Neil, 1997; Martinez-Alier et al., 1998; Munda, 2008). Moreover, several scholars (Vatn, 2005; Bromley and Päävola, 2002; O’Neill, 2011; Hodgson, 2012) argue that the success of any sustainable development action is conditional on actors having a shared understanding of the norms of action, which have universally-agreed upon value. Reaching this understanding requires that each person detach from his or her own individual goals in order to take into account others' interests. Breaking the tight link between individual welfare and one's choice of action is termed 'commitment' by Sen $(1977 ; 2002)$. For Sen as for a number of other scholars in ecological economics (O'Hara, 1996; Douai, 2009; Lo and Spash, 2013), recourse to open and free deliberation among actors creates the necessary conditions for this commitment. By creating a context favorable to the coordination of interpersonal actions (Lo, 2013), deliberation encourages people to call on a kind of reasoning that privileges the 'we' over the 'I' (Vatn, 2005). Thus, deliberation promotes an awareness of personal responsibility towards others and, in this way, fosters a better integration of collective values into individual action choices (Sen, 2009).

We seek here to modify and complement these arguments in order to take into account the specific challenge that moral commitment represents for a business person, since this commitment is only conceivable on the condition that it remains compatible with the company's continued economic profitability (Hartman et al., 2007 ; Pies et al., 2009). Thus, in the specific cases studied here of farm businesses, we argue that farmers' adoption of a kind of reasoning that is sensitive to others' concerns about the environment does not occur only in moral terms. Rather, such adoption requires, first, that farmers be convinced that alternative practices exist and are sufficiently effective, so that they can reduce the negative impact on natural resources without affecting their profits. Second, embracing this new way of thinking also necessitates a re-conceptualization of the profession of 'farmer' around the new skills needed when moving away from automatically using chemicals to fight pests (for 
example, observation, planning ahead, and reactivity). ${ }^{2}$ Therefore, we consider that the purpose of interactive debate is not merely to ground the validity of these new moral obligations in reason (Lo and Spash, 2013). In addition, the goal ${ }^{3}$ of debate is to provide a reasoned basis for the 'truth' of new technical knowledge (for example, using mechanical weeding practices rather than chemical) and to foster the emergence of new individual capacities for action (such as the ability to evaluate and decide for oneself which practices to use depending on the context). ${ }^{4}$

For these reasons, and considering the particular challenge of a moral commitment for a farm business (i.e. the need to maintain profitability), we examine the ability of communicative praxis to make actors reflect on the normative, technical, and experiential knowledge that serves as the basis for their reasons for acting. To do this, we will now delve deeper into the mechanisms of deliberation, by applying Habermas' theory of communicative action to actors from farming businesses.

\subsection{Changing the Reasons for Action through Communicative Praxis}

For Habermas (1981), communicative praxis is based on a form of rationality that he qualifies as communicative. Communicative rationality seeks to achieve agreement through language about the context of action. To achieve this agreement, participants produce social valuations of their behavior. To do this, they raise and test each other's validity claims, which can deal with knowledge coming from "the objective world (as the totality of all entities about which true statements are possible); the social world (as the totality of all legitimately regulated interpersonal relations); [and/or] the subjective world (as the totality of all the experiences of the speaker to which he has privileged access)" (Habermas, 1981, p. 100). Each one of these worlds corresponds to a different model of action. Thus, Habermas (1981) links the objective world to teleological action, the social world to normative action, and the subjective world to dramaturgical action. Certain aspects of these three action models, as well as the knowledge on which they are based, can be used by actors to rationalize their discourse. For example: $:^{5}$

- A person may argue that increasing preventative crop treatment is the only possible way to effectively fight against pest and disease and thus to protect oneself from the related risk of crop loss. For the other participants, is this assertion 'true'?

\footnotetext{
${ }^{2}$ The professional expertise of farmers, as it was conceptualized in the 1960s, is largely based on automatically implementing the technical protocols that they have been given, without question or reflection. The use of preventative chemical treatments in this framework is thus considered as the surest way to limit crop loss.

${ }^{3}$ The terms of this goal have been deduced from the objectives of the AEMs studied here (see the Text Box below on the Regional AEM-WFDs).

${ }^{4}$ The integrated approach that these AEMs seek to promote is related to the 'reasoned' approach to agriculture in France (see note 16). This method involves harmoniously combining several methods (biological, physical, and chemical) to fight against crop pests and to thereby reduce the use of chemicals. Being able to evalute theconsequences of possible actions and to decide on the combination of action choicespresupposes the ability to takeintoaccount multiple contextual variables (climatology, soil type, intercropping, etc.).

${ }^{5}$ The examples that follow illustrate the validity claims of the knowledge put forward by certain actors during this research.
} 
- A person may argue that recycling the water used to clean chemical sprayers is a behavioral norm that should be followed, because it is based on reason. ${ }^{6}$ For the other participants, is this a valid norm?

- A person may argue that the presence of weeds in plots is incompatible with the expertise involved with the profession of farming. For the other participants, is the intention described in this lived experience sincere?

Communication is thus seen as an argumentative process during which the speakers take a hypothetical attitude towards the knowledge that is problematized during the exchange and are led to question the validity of their choices. We seek to understand the effects of this communicative process during the period (3 years) in which the two AEM programs were implemented. In this way, we examine the learning that happens over time, a methodological choice justified by Bakhtin's work.

\subsection{A Dialogic conception of speech}

The communicative process among actors (advisors and farmers) will be analyzed here by considering the eminently dialogic purpose of all discourse, following Bakhtin (1986). According to him, any speech act inevitably carries the trace of a relationship to other partners in a verbal exchange. This speech act is always filled with reaction-responses to the utterances of others (agreement, objection, disagreement). For Bakhtin, these reactionresponses are not necessarily triggered immediately in a face-to-face exchange. They may emerge later in subsequent speech, which he terms a "delayed reaction." Therefore, as he rightly points out, "[a]ny utterance is a link in a very complexly organized chain of other utterances" (Bakhtin 1986, p. 69).

Drawing on Bakhtin, we consider that the speech of farmers and advisors collected in semi-structured interviews enables us to retrace their dialogic relationship that occurs at a distance and over time. The reaction-responses to the utterances of other actors (farmers, advisors, government workers, members of civil society, etc.) that are contained in the discourses collected, therefore, inform us about the communicative rationality at work within the two cooperatives studied. In so doing, we have a two-fold objective: (i) to understand the ways in which Habermas' three forms of action interconnect during a communicative process; and (ii) to determine the influence of these interconnections on changing actors' preferences and, specifically, on their taking into account new moral obligations regarding the environment.

The validity of these two propositions was tested by studying two cases of Regional Agro-environmental Measures - Water Framework Directives (see Tex Box below), managed by two farmers' cooperatives. The reasoned deliberation that occurred over time between the farmers and advisors of these two cooperatives was the focus of our study.

\section{Textbox: Regional Agro-environmental Measures - Water Framework Directive}

Adopted in 2000 by the European Union Council, the Water Framework Directive(WFD) is a policy framework on water applicable throughout the EU. It sets objectives that member-states must reach to preserve and restore the quality of surface and groundwater within the EU. To facilitate reaching these targets, and notably to reduce the impact of diffuse agricultural pollution on water quality, public authorities rely on the AEM incentive program. Targeting farms located near drinking water basins, these AEM-WFDs seek to financially encourage farmers to reduce the use of chemical pesticides and

${ }^{6}$ The communicative action model, therefore, assumes that moral questions can be rationally decided within the framework of discussion (Habermas, 1983, 1991). 
fertilizers by using methods such as 'reasoned' agriculture, mechanical weeding such as the weeder harrow, or by giving them incentives to introduce crops into their rotations that require few inputs, such as pulses. In France, these AEMs have been applied regionally in order to better take into account the specificities of the local contexts in which these programs are applied, termed Regional Agroenvironmental Measures - Water Framework Directives. Regional AEM-WFD management is entrusted to the traditional groups for agricultural public policy in the region (local authorities, county extension services, farmers' unions). More unusually, as is the case in our study, managing these programs has been assigned to businesses such as the farmers' cooperatives.

\section{Data, Method, and Results}

Exchanges between advisers and farmers are essentially verbal and are communicative action (Habermas, 1976, 1981). Being mutually consensual and aiming at sharing experiences and knowledge, this communication process falls under discourse ethics (Habermas, 1991). It is primarily during these exchanges that the validity of knowledge is tested. Understanding this communicative process requires discourse analysis (Harris and Dubois-Charlier, 1969). Before going into further detail about our method of discourse analysis, we will first describe the context in which relationships between advisers and farmers were established (the empirical material), and then how we compared them.

\subsection{Case Study}

The cases chosen were two cooperatives ${ }^{7}$ located in the Midi-Pyrenees Region of southern France, which are responsible for the technical support of farmers having signed up for the AEM programs. Both cooperatives are of comparable size, both in terms of their collection zone as well as their annual sales. Specialized in field crops, they both have a relatively similar range of activities (supplying farms with pesticides and plant protection products, collecting and marketing the harvest) and cater to the same category of farmers (mediumsized farms).

While sharing several common features and regularly communicating together, these cooperatives opted for two different strategies for managing the regional AEMs. The first cooperative (referred to henceforth as Person-Coop) established a system of personalized advisers. The sole task of these advisers was to assist the member-farmers in implementing the regional AEM program. The second cooperative chose a system of advisers by geographical zone. For these advisers, the task of advising farmers in the regional AEM program was in addition to their traditional role of technical and commercial support of farmers in their territory (henceforth Region-Coop).

Within these two cooperatives, the first phase of interviews was conducted between May and September 2009. Additional interviews were carried out between June and September 2012. This enabled us to follow the implementation of these programs over time. Thirty-five farmers and six agricultural advisers were interviewed (the number of actual respondents was evenly divided between the two cooperatives), providing us with information about their communicative interactions. Thus, these people interacted over a distance in space and time and in a repeated manner, which qualifies as Bakhtin's 'delayedresponse' deliberative process.

\footnotetext{
${ }^{7}$ Farmers' cooperatives in France generally pool together the harvest of a givencrop and are responsible for selling the harvest. Theyalso pool purchasing of materials, regulate certain aspects of production, and sellchemicals to farmers.
} 
Interviews with advisers primarily addressed the changes caused by the program in terms of their relationships with farmers (program goals and content of their visits and messages). Interviews with farmers focused on their reasons for joining the regional AEM program, the technical and organizational changes resulting from the contracts, access to advice and information, their opinions on the different types of advising, and their relationship to the cooperative. These interviews were semi-structured, in conjunction with Habermas' analytical framework. They were then transcribed in their entirety in order to be processed using discourse analysis tools (ALCESTE method of discourse classification and similarity analyses), which will be described in the next section.

\subsection{Discourse Analysis}

Using Habermas' theory of communicative action, the discourse analysis method used here seeks to identify the influence of communicative praxis on changing farmer-entrepreneurs' preferences. This influence was identified through the speech utterances ${ }^{8}$ of advisors and farmers that were collected in interviews.

Lexicometry, or textual statistics, (Lebart et al., 1994) provides statistical indicators and visual charts for analyzing the complex information contained in texts. This kind of detailed analysis of the language used by farmers and advisors enables us to uncover the deeper mechanisms at work in the deliberative process between them and to trace changes in their preferences. Various methods of analysis are combined to highlight specific aspects of a text or to link semantic dimensions of a discourse to the institutional or contextual features of the discourse's enunciation. The appendix explains the various statistical methods that provided the results in the next subsection (ALCESTE method of classification and similarity analysis). We also introduced variables of interest in order to link certain aspects of the context to the semantics of the discourses. These variables were: (i) the individuals interviewed (from 1 to 41); (ii) the type of actor interviewed (type_farmer or type_adviser); (iii) the type of advisory strategy implemented (strat_regionfor advisory by zone and strat_personfor personalized advisory); and (iv) the type of actor from each advisory strategy (cross_adv_pers and cross_farm_pers for advisers and farmers, respectively, from the Person-Coop; and cross_adv_reg and cross_farm_reg for advisers and farmers, respectively, from the Region-Coop). We then used the IRaMuTeQ textual toolbox (Ratinaud and Dejean, 2009; Ratinaud and Marchand, 2012) on the interview transcripts. ${ }^{9}$ The methodology proceeded in three steps:

- First, we determined the structure of the discourses using the ALCESTE method of textual classification (Reinert, 1993). This method provides a descending hierarchical classification of words representing semantic contexts and identifies the variables related to these semantic contexts (Figure 1);

- Second, to explain the structure of the discourse, we introduced variables of interest and reconstructed the communication through semantic connections by means of a basic network analysis: if two individuals use the same semantic dimension highlighted in the ALCESTE

\footnotetext{
${ }^{8}$ An utterance isdefined by Habermas as an "elementary unit of speech" (Habermas, 1976, p. 26). In the ALCESTE classification, the association betweenwordsforms a contextthatgives the discourseitsmeaning. Technically, an utteranceisthus a context, whichisconventionallycharacterized as a givennumber of words (here, 40 ).

${ }^{9} \mathrm{IRaMuTeQis}$ an open-source freeware $\mathrm{R}$ interface (downloadableat http://www.iramuteq.org/). It encapsulatesseveral lexicometry toolssuch as the ALCESTE classification, wordclouds, basic textualstatistics, and graphs of words. The interface isstill in development.
} 
classification, they are related through a semantic link. The network aimed at identifying the variables that would explain the structure of the discourse;

- Third, we analyzed the content of the discourses according to the variable that most significantly determined the discourses' structure. We conducted a similarity analysis that revealed the most frequent co-occurrence of words (Figure 3), thereby shedding light on the mental maps/conceptualizations of the farmers and advisors.

\subsection{Results}

Reconstructing the semantics of discourses used in the regional AEMs required labeling the categories, by assessing why words belonging to a given category were significantly used together (and not with those present in other categories). Figure 1 shows the results of the descending hierarchical classification of the interviews with farmers and advisers. The final classification showed that their speech contained six distinct categories of concepts/terms. Each of these categories regrouped terms that have a common denominator of meaning. Category 1 contained terms describing the economic and regulatory framework farmers must deal with. Category 2 words referred to the current chemical methods and techniques of farming used. Category 3 was an inventory of crop farming at the farm scale. Category 4 terms addressed the relationship of the agricultural sector to the outside world (e.g. the new conditions of water use that are gradually being imposed on agriculture were seen as constraints, but also as norms for action). Category 5 covered the mechanical methods that are alternatives to chemical treatments, methods which are used in reaching the environmental goals set by the regional AEM. Category 6 words focused on the cooperatives' support of farmers in the regional AEM project (adviser/farmer relationship) through the cooperatives' and the advisors' responsibilities.

The ALCESTE method of classification constructs a descending hierarchical classification of a text (here, all the interviews with farmers and agricultural advisers), which is understood as a single semantic unit. ${ }^{10}$ This classification is obtained from a contingency table in which all the words ${ }^{11}$ used in the interviews are placed in rows, and text segments or utterances (defined as a given number of words, in our case 40) are placed in columns. The table then highlights the number of times a given word is used in a given text segment. An algorithm first determined the two-class grouping that was the most different in terms of word occurrences, and then successively divided the biggest group into two different subgroups (i.e. a group that contains the words not contained in the other sub-group). The algorithm stopped when the two sub-groups obtained from the division of the last group, which is the largest, were not significantly different from each other (assessed in terms of chisquare on the proportion of words contained in each of these sub-groups). ${ }^{12}$ The list of words that defined the discourse contexts and the semantic dimensions of communicative action are then represented as a word classification (Figure 1).

\footnotetext{
${ }^{10}$ In our case, thisincluded the entire range of subjectsdiscussed in the interviews and the farmers' and agriculture advisers' perspectives on the regional AEM projectimplementation, whichguaranteedthissemanticunity (i.e. the subject of the wholetext).

${ }^{11}$ Words are defined as an interruptedstream of signs, mainlyletters or numbers.

${ }^{12}$ In ALCESTE classification, chi-square does not have its standard meaning. Here, for one word, a chi-squared value of 3.84 corresponds to a $0.05 \%$ probabilitythat the association of a word to a certain categoryoccurredrandomly.
} 
Figure 1 - Descending Hierarchical Classification of Actors' Speech on Regional AEM Implementation

\begin{tabular}{|c|c|c|c|c|c|c|c|c|c|c|c|}
\hline \multirow{2}{*}{\multicolumn{2}{|c|}{$\begin{array}{c}\text { Category } \mathrm{n}^{\circ} 1(21 \%) \\
\text { Economic and } \\
\text { regulatory context }\end{array}$}} & \multirow{2}{*}{\multicolumn{2}{|c|}{$\begin{array}{c}\text { Category } n^{\circ} 2(19 \%) \\
\begin{array}{c}\text { Existing agricultural } \\
\text { attitudes }\end{array}\end{array}$}} & \multirow{2}{*}{\multicolumn{2}{|c|}{$\begin{array}{c}\text { Category } n^{\circ} 3(9 \%) \\
\text { Crop farming }\end{array}$}} & \multirow{2}{*}{\multicolumn{2}{|c|}{$\begin{array}{c}\text { Category } n^{\circ} 4(14 \%) \\
\text { Societal norms }\end{array}$}} & \multirow{2}{*}{\multicolumn{2}{|c|}{$\begin{array}{c}\text { Category } n^{\circ} 5(17 \%) \\
\text { Agricultural innovative } \\
\text { practices }\end{array}$}} & \multicolumn{2}{|c|}{ Category $n^{\circ} 6(20 \%)$} \\
\hline & & & & & & & & & & Cooperatives & function \\
\hline Words & $x^{2}$ & Words & $x^{2}$ & Words & $x^{2}$ & Words & $x^{2}$ & Words & $x^{2}$ & Words & $x^{2}$ \\
\hline think & 120 & dose & 465 & wheat & 1022 & agriculture & 233 & weeder & 609 & technician & 520 \\
\hline economy & 109 & use & 209 & sunflower & 464 & live & 216 & curry & 487 & cooperative & 387 \\
\hline mandatory & 80 & treatment & 197 & rape & 372 & france & 179 & ploughting & 347 & follow & 328 \\
\hline $\begin{array}{l}\text { question } \\
\text { feel }\end{array}$ & 80 & $\begin{array}{l}\text { product } \\
\text { ift* }\end{array}$ & 172 & $\begin{array}{l}\text { maize } \\
\text { auintal }\end{array}$ & 331 & consumer & 141 & sowing & 345 & $\begin{array}{l}\text { Person-Coop**** } \\
\text { advise }\end{array}$ & 286 \\
\hline $\begin{array}{l}\text { feel } \\
\text { thing }\end{array}$ & 73 & & 166 & $\begin{array}{l}\text { quintal } \\
\text { seed }\end{array}$ & 325 & country & 130 & sow & 340 & advise & 251 \\
\hline $\begin{array}{l}\text { thing } \\
\text { assistance }\end{array}$ & $\begin{array}{l}72 \\
69\end{array}$ & $\begin{array}{l}\text { weed-killer } \\
\text { reduce }\end{array}$ & $\begin{array}{l}155 \\
154\end{array}$ & $\begin{array}{l}\text { seed } \\
\text { durum }\end{array}$ & $\begin{array}{l}305 \\
193\end{array}$ & $\begin{array}{l}\text { eat } \\
\text { planet }\end{array}$ & $\begin{array}{l}104 \\
100\end{array}$ & $\begin{array}{l}\text { plought } \\
\text { soil }\end{array}$ & $\begin{array}{l}335 \\
203\end{array}$ & $\begin{array}{l}\text { meeting } \\
\text { chamber }\end{array}$ & 192 \\
\hline $\begin{array}{l}\text { asssistance } \\
\text { earn }\end{array}$ & $\begin{array}{l}69 \\
69\end{array}$ & $\begin{array}{l}\begin{array}{l}\text { reduce } \\
\text { insecticide }\end{array} \\
\text { a }\end{array}$ & $\begin{array}{l}154 \\
144\end{array}$ & $\begin{array}{l}\text { durum } \\
\text { year }\end{array}$ & $\begin{array}{l}193 \\
174\end{array}$ & $\begin{array}{l}\text { planet } \\
\text { farmer }\end{array}$ & $\begin{array}{l}100 \\
99\end{array}$ & $\begin{array}{l}\text { soll } \\
\text { hoe }\end{array}$ & $\begin{array}{l}203 \\
178\end{array}$ & $\begin{array}{l}\text { chamber } \\
\text { member }\end{array}$ & 167 \\
\hline equipment & 62 & fungicides & 144 & protein & 153 & sell & 96 & month & 167 & $\begin{array}{l}\text { member } \\
\text { Region-Coop**** }\end{array}$ & $\begin{array}{l}10 / \\
132\end{array}$ \\
\hline phytosanitary & 61 & weed-killing & 136 & rotation & 129 & image & 95 & direct & 140 & service & 130 \\
\hline charge & 59 & fungicide & 130 & barley & 118 & import & 87 & weed & 139 & technique & 114 \\
\hline change & 56 & treate & 128 & quality & 115 & production & 84 & oat & 125 & warehouse & 110 \\
\hline continue & 55 & disease & 83 & nitrogen & 97 & environment & 84 & false & 120 & & 107 \\
\hline pac* & & produce & 80 & average & 83 & quality & 84 & cover & 112 & information & 92 \\
\hline money & 52 & reduce & 79 & sensitive & 79 & worldwide & 78 & $\mathrm{mai}$ & 110 & & 75 \\
\hline ness & 51 & $\mathrm{p}$ & 77 & cropping-plan & 78 & feed & 78 & sunflower & 108 & together & 72 \\
\hline 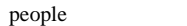 & 50 & efficiency & 71 & diversify & 77 & price & 78 & land & 108 & occupy & 72 \\
\hline & 48 & & 66 & & 76 & pollution & 69 & crazy & 102 & propose & 71 \\
\hline grenelle*** & 47 & expensive & 65 & ture & 71 & & 68 & ean & 10 & & \\
\hline bonus & 45 & aphid & 63 & variety & 70 & europe & 67 & spring & 100 & sector & 65 \\
\hline Variables & p-val & Variables & p-val & Variables & p-val & Variables & p-val & Variables & p-val & Variables & p-val \\
\hline Individuals & & Individuals & & Individuals & & Individuals & & Individuals & & Individuals & \\
\hline$\overline{01 \text {-farm-reg }}$ & $5.3 \%(\mathrm{NS})$ & $\overline{01-f a r m-r e g}$ & $15.2 \%(\mathrm{NS})$ & 14-farm-reg & $<0.01 \%$ & $\overline{02 \text {-farm-reg }}$ & $0.8 \%$ & $\overline{19-f a r m-r e g}$ & $<0.01 \%$ & $\overline{06-f a r m-r e g}$ & $5.7 \%(\mathrm{NS})$ \\
\hline 02 -farm-reg & $9.3 \%$ (NS) & 12-farm-reg & $14.4 \%$ (NS) & 16-farm-reg & $12.3 \%(\mathrm{NS})$ & 03-farm-reg & 0.4 & $24-\mathrm{f}_{\mathrm{c}}$ & $<0.8$ & 21-adv-reg & $<0.01 \%$ \\
\hline 06-farm-reg & $3.5 \%$ & 14-farm-reg & $3.6 \%$ & 19-farm-reg & $<0.01 \%$ & 04-farm-reg & $<0.01 \%$ & 25 -farm-pers & $<0.01 \%$ & 22-adv-reg & $<0.01 \%$ \\
\hline 07 -farm-reg & $0.2 \%$ & 17 -farm-reg & $9.9 \%$ (NS) & 25 -farm-pers & $<0.01 \%$ & 05-farm-reg & $<0.01 \%$ & 27 -farm-pers & $<0.01 \%$ & 23-adv-reg & $9.5 \%(\mathrm{NS})$ \\
\hline 08-farm-reg & $2.9 \%$ & 26-farm-pers & $11.9 \%$ (NS) & 28 -farm-pers & $0.2 \%$ & 08-farm-reg & $0.2 \%$ & 28 -farm-pers & $<0.01 \%$ & 40-adv-pers & $<0.01 \%$ \\
\hline 09-farm-reg & $1.7 \%$ & 27-farm-pers & $8.4 \%(\mathrm{NS})$ & 33-farm-pers & $<0.01 \%$ & 10-farm-reg & $1.0 \%$ & 29-farm-pers & $<0.01 \%$ & & \\
\hline 15 -farm-reg & $<0.01 \%$ & 34-farm-pers & $<0.01 \%$ & 36-farm-pers & $<0.01 \%$ & 11-farm-reg & $<0.01 \%$ & 32-farm-pers & $<0.01 \%$ & & \\
\hline 17-farm-reg & $11.7 \%(\mathrm{NS})$ & 37-farm-pers & $1.3 \%$ & 40-adv-pers & $<0.01 \%$ & 12-farm-reg & $0.9 \%$ & 33-farm-pers & $<0.01 \%$ & & \\
\hline 20-adv-reg & $<0$ & 40-adv-pers & $2.8 \%$ & 41-adv-pers & $8.8 \%(\mathrm{NS})$ & 13-farm-reg & $12.4 \%(\mathrm{NS})$ & 36-farm-pers & $15.0 \%(\mathrm{NS})$ & & \\
\hline 21-adv-reg & $<0.01 \%$ & 41-adv-pers & $0.2 \%$ & & & 14-farm-reg & $0.1 \%$ & 39-farm-pers & $<0.01 \%$ & & \\
\hline 22-adv-reg & $<0.01 \%$ & & & & & 15-farm-reg & $7.7 \%$ (NS) & & & & \\
\hline 23-adv-reg & $<0.01 \%$ & & & & & 16-farm-reg & $<0.01 \%$ & & & & \\
\hline 26-farm-pers & $0.5 \%$ & & & & & 18-farm-reg & $1.8 \%$ & & & & \\
\hline $\begin{array}{l}\text { 30-farm-pers } \\
35 \text {-farm-ers }\end{array}$ & $\begin{array}{l}0.3 \% \\
115 \%\end{array}$ & & & & & 38-farm-pers & $3.4 \%$ & & & & \\
\hline$\frac{3 \text { 3-farm-pers }}{\text { Advisory strategy }}$ & & Advisory strategy & & Advisory strategy & & $\frac{\text { 3-farm-pers }}{\text { Advisory strategy }}$ & & Advisory strategy & & $\overline{\text { Advisory strategy }}$ & \\
\hline$\frac{\text { regionalized }}{\text { Trenof }}$ & $<0.01 \%$ & personalized & $0.9 \%$ & personalized & $<0.01 \%$ & $\frac{\text { regionalized }}{\text { Typof }}$ & $<0.01 \%$ & personalized & $<0.01 \%$ & Typeof actor & \\
\hline$\frac{\text { lype or actor }}{\text { adviser }}$ & $<0.01 \%$ & Type or actor & & Iype or actor & & $\frac{\text { lype or actor }}{\text { farmer }}$ & $<0.01 \%$ & Typer or acior & $<0.01 \%$ & Iyper or acior & $0.01 \%$ \\
\hline$\frac{\text { adviser }}{\text { Type/Strategy }}$ & & Type/Strategy & & Type/Strategy & & $\frac{1}{\text { Typel/Strategy }}$ & & Type/Strategy & & Type/Strategy & \\
\hline $\begin{array}{l}\text { adv-reg } \\
\text { farm-reg }\end{array}$ & $\begin{array}{l}<0.01 \% \\
<0.01 \%\end{array}$ & $\overline{\text { adv-pers }}$ & $0.1 \%$ & $\begin{array}{l}\text { adv-pers } \\
\text { farm-pers }\end{array}$ & $\begin{array}{l}<0.01 \% \\
<0.01 \%\end{array}$ & farm-reg & $<0.01 \%$ & farm-pers & $<0.01 \%$ & $\begin{array}{l}\text { adv-pers } \\
\text { ady-res }\end{array}$ & $<0.01 \%$ \\
\hline
\end{tabular}

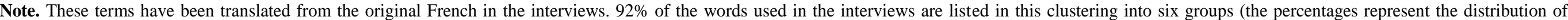

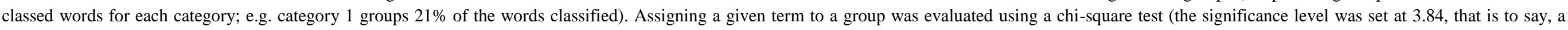
$0.05 \%$ chance that a word was assigned to a group randomly).

*acronyms: pac (common agricultural policy in Europe); ift (indicateur de fréquence de traitementsphytosanitaires, a guideline for how often plant protection products must be applied).

** grenelle: group of French government agreements on environmental management that resulted from roundtable discussions signed between 2007 and 2009.

*** Person-Coop and Region-Coop refer to the two names of the cooperatives studied.

NS refers to non-significant variables, with a $5 \%$ significance threshold.

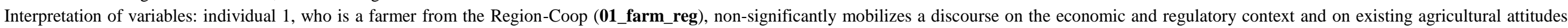

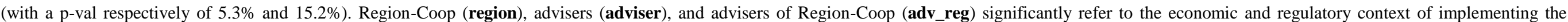
regional AEM (category 1). Note that the advisers of Region-Coop (adv_reg) also significantly refer to the discourse on cooperative functions. 
The purpose of ALCESTE's method of classification is to build exclusive categories of words, i.e. the words appearing in a given category are not likely to appear in another one (unless they are used in very different contexts). However, the aim of this paper is to analyze the ways in which the various semantic dimensions of the classification are connected to each other and why, which in turn reveals key information about the farmers' and advisors' attitudes. To so do, we reconstructed the network of mutual understanding by connecting individuals that referred to the same semantic dimension. This 'cognitive network' of individuals mobilizing the same semantic categories of discourse is displayed in Figure 2. In the figure, we first distinguish farmers from advisers (resp. circles and triangles), and then individuals from the Region-Coop (territorialized advice) from those from the Person-Coop (personalized advice) (resp. black and white items).

\section{Figure 2 - Cognitive Networks of Individuals and Places of Mutual Understanding}

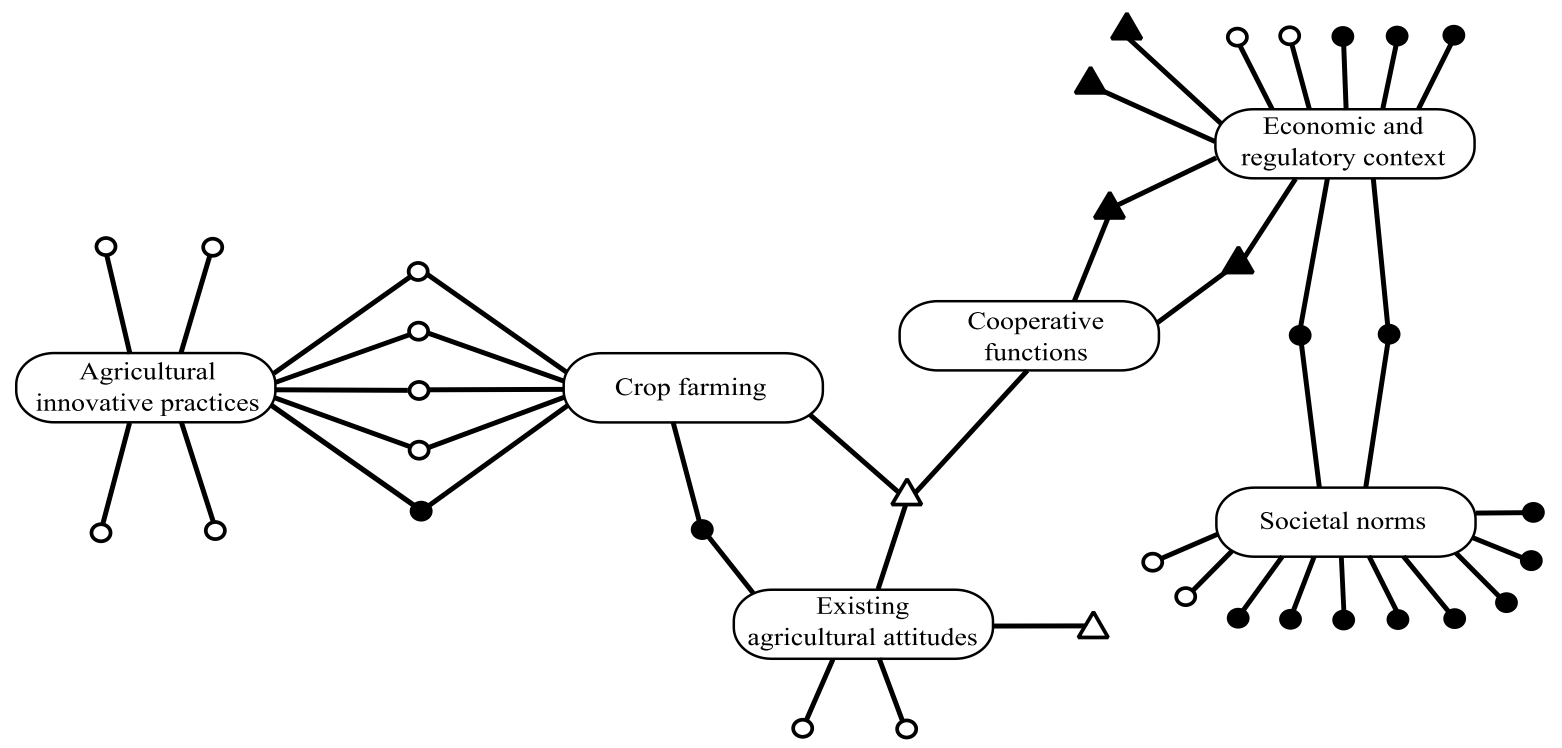

Note. Circles represent farmers; triangles represent advisers; black items are for the Region-Coop (regionalized); white items are for the Person-Coop (personalized advice). The large rounded rectangles represent the six categories of their discourses shown in Figure 1.

This network of mutual understanding (Figure 2), as we have reconstructed it, enables us to significantly differentiate the discourses depending on the cooperative that the actors belonged to (farmers and advisors). In communication between farmers and advisors of the Region-Coop, the subjects they spoke about were almost exclusively technical and agronomical. These subjects were discussed in connection with the new economic and regulatory context of farming, but without necessarily being directly connected to the new environmental challenges that agricultural actors must face. However, communication between farmers and advisors from the Person-Coop focused more on society's new expectations of agriculture, and their discussions focused on the technical and professional implications of taking into account these expectations. Consequently, it appears that the 'advising strategy' (personalized or regional) had a greater influence on which subjects were discussed than the 'type of actor' (farmer or advisor). In particular, the process used in advising farmers about the AEM appears to have determined the nature of knowledge invoked during the communicative process and the ways in which this knowledge was tested 
in the reasoning of the debate. The following section will explore these aspects in greater detail.

\section{Farmer-Adviser Relationships and Commitment to the Regional AEM}

This section discusses the results of the discourse analysis presented in the previous section and extends them by means of a similarity analysis. (see the appendix). This kind of analysis enables us to more closely examine the impact of different advising strategies (advisors by region vs. personalized advisors) on changing practices towards using fewer chemicals. It therefore informs us about the nature of learning that occurs in the communicative process. ${ }^{13} \mathrm{We}$ begin by discussing the influence of the two cooperatives' advising strategy on verbalized norms. Then, to better understand the results observed, we analyze how the knowledge from the objective world, the normative world, and the dramaturgical world were interconnected in these two cooperatives.

\subsection{The Influence of Advising Strategies on the Subject of Norms}

A similarity analysis of the discourse used by each of the cooperatives (Figure 3) shows first, how norms may serve to legitimize changes in processes (using fewer chemicals) and second, how in return the choice of practices may reinforce the validity of norms from the actors' perspective and, in particular, their practical value (i.e. their usefulness in conceptualizing and doing agricultural work). To this end, the strategies implemented by the cooperatives (that we have reconstructed through verbal interactions among actors) can be distinguished in two ways: (i) the way in which advisors take into account farmers' daily concerns when disseminating innovative techniques and making them credible to the farmers; and (ii) the way in which current knowledge about the business of farming is connected to the emerging expectations of society about preserving the environment.

\section{Figure 3 - Similarity Analysis of the Two Cooperatives' Discourses}
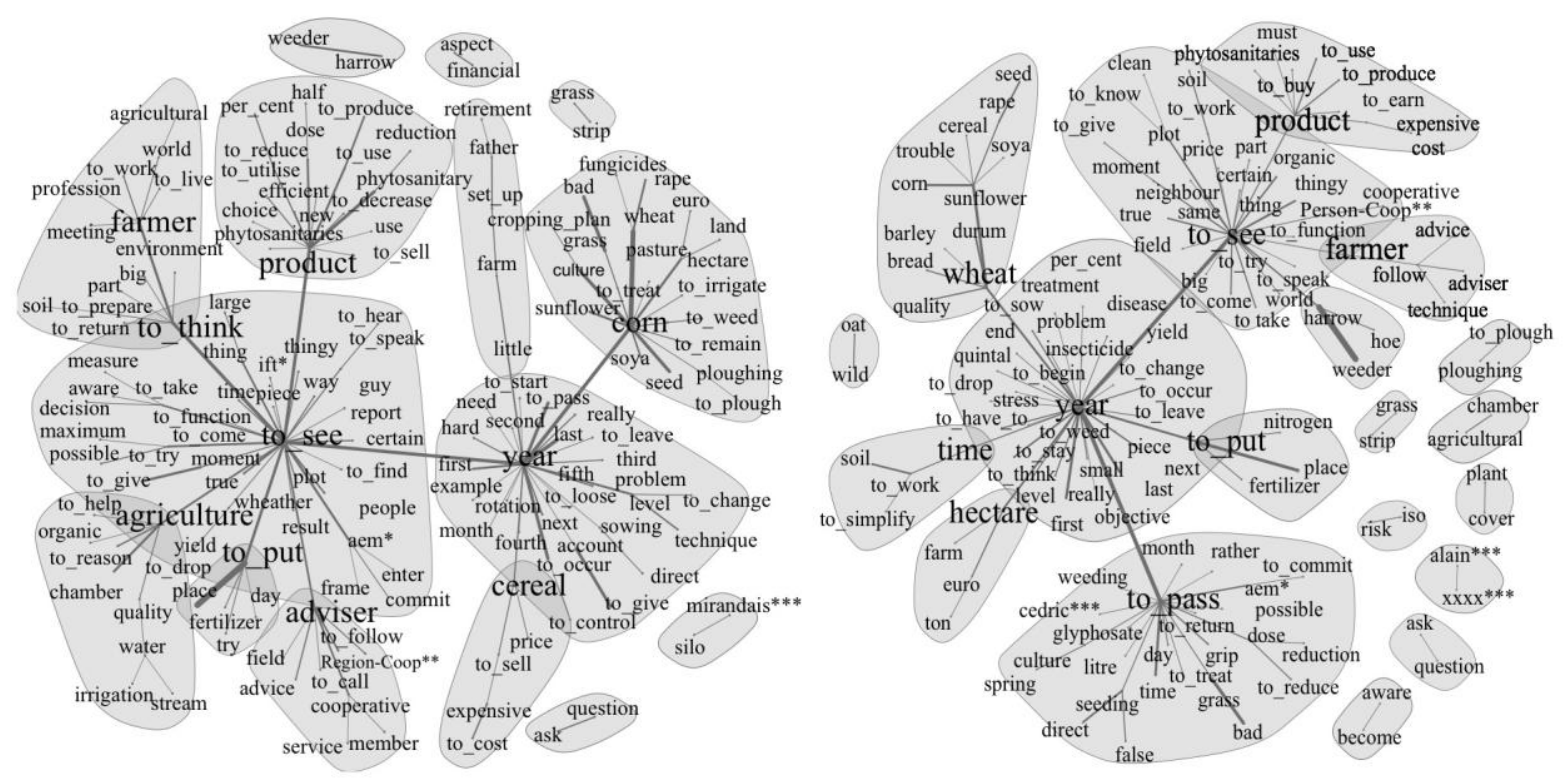

\footnotetext{
${ }^{13}$ For Habermas (1981), the process of debatebetween participants isnecessarily a source of learning. Whenactors are confrontedwith a contradiction of theirhypotheses, theynecessairly are led to call into question the validity of theirknowledge.
} 
Note. The threshold of frequency of occurrence selected: 10. The figures represent the words frequently used in the same text segments (determined when creating the contingency table in the ALCESTE classification method) in each cooperative's discourse. The thicker the line between two words, the higher the frequency of cooccurrence, and the stronger the association of these two words. The rounded shapes result from the similarity analysis: for each triad, only the two most frequent relationships have been kept (see Appendix). Only the words that appear more than ten times have been chosen for analysis.

*acronyms: ift (indicateur de fréquence de traitementsphytosanitaires- a guideline for how often plant protection products must be applied); aem (agro-environmental measure)

** Person-Coop and Region-Coop refer to the two names of the cooperatives studied; mirandais refers to the region of the city of Mirande at the heart of Region-Coop's territory.

*** alain $\mathrm{xxx}$ is the name of the person in charge of implementing the regional AEM in Person-Coop; cédric is the name of one of the two advisers interviewed.

The different strategies adopted by the two cooperatives to support farmers in changing practices can be found translated into their discourses. In general, these discourses reveal two different ways of interacting with farmers (see Figure 3). The discourses within the personalized-advisor cooperative are filled with references to the name of the person in charge of the AEM and of the advisors (alain xxx, cédric). ${ }^{14}$ The discourses within the territorial-advisor cooperative refer more to elements of the regional context of the AEM (mirandais - the name of the region where Region-Coop is located). In Person-Coop, the interactions among actors are very personalized and built around the collectively-recognized leadership of certain people. In one of many examples, a farmer interviewed stated, "So, already, we trust the technical team of the Person-Coop, especially Alain ${ }^{15}$...and so, every time he had us do things that went in that direction, it [the result] was positive."However, in Region-Coop, relationships between farmers and advisors are more impersonal; the indefinite pronoun in French 'on' predominates in the actors' discourse. In addition, the farmers' local and everyday concerns are prevalent.

More specifically, comparing the cooperatives' discourses in detail enables us to evaluate the depth of the proposed changes in practices and the extent to which they break with the knowledge in force and, in particular, with the normative knowledge that legitimizes action. Three elements characterized the different ways that agricultural norms and practices were connected (i.e., the normative world and the objective world): the relationship between the field of expertise and new environmental norms (norms that may refer to implementing agroecological principles); the aim of the intercommunication; and the actors' perception of norms.

- Is expertise brought to the fore in the cooperative in such a way as to legitimize new environmental norms?

Within Region-Coop, interactions between advisors and farmers were, for the most part, centered on the governmental and regulatory procedures that govern farming practices. Class 1 of the ALCESTE classification was the only one that included advisors and farmers from Region-Coop, with a significance threshold of less than $0.01 \%$ (see Figure 1). Above all, their intercommunication dealt with the compatibility of these procedures with existing economic norms focused on agricultural yield (price, to sell, to cost,expensive, see Figure 3a). As one farmer from

\footnotetext{
${ }^{14}$ Thesenamesrefer to one of the perosnalizedadvisors and the person in charge of the regional AEM within the cooperative, respectively.

${ }^{15}$ Alain, in charge of the regional AEM for Person-Coop, wasgreatlytrusted by the farmers. In particular, this confidence resutledfrom the success of projectsthathehadinitiated in the past (such as organizing a qualityprocess, implementing a newsletter on techniques, creating groups for discussion and sharing experiencesamongfarmers).
} 
this coop stated, "For [the Regional AEM] to be effective, there must not be any impact on yield. After all, it needs to be said, it's the yield that determines the financial result." Since the actors felt that the goals pursued by these procedures (cap, financial, bonus - see Figure 1, class 1) did not fundamentally call into question the productivist-intensive agricultural paradigm, they were not driven to re-question the validity of the productivist norms on which their professional expertise was based. On the contrary, the prevailing discourse in Person-Coop centered more on alternative techniques to current agricultural practices (plant cover, weeder harrow, grass strip, to_plough, direct seeding). Their discourse was characterized by a more factual vocabulary, marked by the predominance of technical and agronomic terms (classes 2, 3, and 5, see Figure 1). The kind of expertise promoted by the cooperative meant that current economic norms were questioned. For example, the actors discussed the possibility of changing their economic calculations to privilege a reduction in the costs of chemicals inputs rather than maximizing yields.

- What are the goals of intercommunication?

In the discourse of Region-Coop, environmental norms were present, but they were rarely connected with the everyday economic preoccupations of farmers. Environmental norms were part of a very general discourse (world, environment, to_live). In fact, there was no explicit link between the farming techniques and environmental norms mentioned (qualityof water for irrigation, Figure 3a) in their discourse. Thus, environmental norms could remain separate and exterior to the economic rationales they used on the farms. In the Person-Coop, however, while general environmental norms were mentioned less explicity than in Region-Coop, they were implicitly at the core of the communicative process when people discussed using alternative techniques instead of chemicals. This was clearly expressed by one of the Person-Coop's advisors, "For me, my aim in this project is to make farmers aware of the impact they have on water quality." The advisors thus focused their discourse on the farming techniques that enabled them to better meet new environmental and social challenges. For these advisors, the goal was to reassure the farmers about the effectiveness of the alternative practices that they recommended (fertilizer, insecticide, problem, to_change- see Figure $3 \mathrm{~b}$ ). One of the advisors in charge of the AEM at Person-Coop illustrates how the personalized approach to advising enabled farmers to overcome their doubts about alternative practices: "Out here in the field, people have this really technical approach. So, we came out here to support them, to reassure them, make them feel secure. That enabled us to show them that it's possible to avoid chemicals, by preventing them from imagining all the catastrophic scenarios..."

\section{- How do the actors perceive these norms?}

In the discourse of actors from Region-Coop, environmental norms such as those dealing with the qualityof water for irrigation (Figure 3a) were above all perceived as obligations (mandatory, see Figure 1, class 1). For example, an advisor said, "There are way too many restrictions...we're killing the profession [farmer] and discouraging people." These norms were perceived as generating extra work (to prepare and to turn the soil, see Figure 3a). On the contrary, farmers in PersonCoop perceived agro-environmental norms as liberating, in that these norms served as a foundation for innovative new practices (to simplify/to work the soil, see Figure 3b). These norms were therefore understood as opportunities for action (Commons, 1934). 
Normative knowledge here was mobilized implicitly in order to profoundly reorganize action and to redefine the moral obligations of agricultural actors towards other members of society. Such was the case, for example, of this farmer who was asked about the reasons why he created a separate zone for filling and washing his sprayers: "That, that's for us, so that after we can have clean water that flows in the fields... because, it's true you know, that when we clean, we always just throw it out. That's why I think that it's necessary to clean. It's necessary to clean more and to treat our water, that's why!" As we can see with the "it's necessary (falloir in French), ${ }^{16}$ the justifications that he provides are of a moral order, not legal.

These results can be interpreted in two different ways. First, that advising strategies determine the effectiveness with which new knowledge is transmitted and the degree to which it is perceived and accepted as worthy of trust. Second, that advising strategies institutionalize at the cooperative level the norms that are already present and, to a certain extent, already shared by the farmer-members. Nevertheless, there is a close connection between advising strategy and the ability of the knowledge transmitted to be legitimated. In the following subsection, we analyze this legitimation processes of new knowledge, that is to say, how it is perceived as credible (or not) in light of Habermas' theory of communicative action.

\subsection{The Recomposition of Communicative Action}

Drawing on Habermas' model, we seek to identify why the discursive strategy used by Person-Coop resulted in a greater change in farmers' actions than did the Region-Coop's discursive strategy. The interviews showed that the farmers' work was organized into categories, which they implicitly linked to one of the three models of action discussed by Habermas (see Figure 4). In the case here:

- Farmers and advisors rationalized their actions by referring to technical knowledge, to proven facts (descriptive knowledge prevailing in teleological action). This type of knowledge was central in the relationship between farmers and agricultural advisers. In particular, this meant advisers having to convince farmers of the 'truth' of alternative methods to chemicals. For the farmers, this may result in tension between proven knowledge, often linked to the use of pesticides, and emerging knowledge, whose effectiveness remains to be proven. Categories 2, 3 and 5 reflect this tension between existing attitudes (such as dose, treatment, fungicide, andinsecticide) and innovative practices (i.e. plant cover, weeder harrow, grass strip, to plough, direct seeding).

- Farmers and advisorsalso justified their actions by referring to knowledge of accepted social norms, to legitimate expectations among people (normative action). This normative dimension of action is present in categories 1 (economy, earn, financial, $\underline{\text { money) }}$ ) and particularly 4 (qualityof the environment, pollutionaspects, obligation to feed the planet). These categories refer to the environmental norms promoted by sustainable development, as well as to economic efficiency norms as a model of action working for the common good (reaching food self-sufficiency by increasing crop yields).

- Finally, farmers and advisors determined their choices of action in light of knowledge from lived experience (dramaturgical action). In the case of agricultural advisers, this type of knowledge was mobilized in elements from categories 1

\footnotetext{
${ }^{16}$ In linguistics, thisverb in French isconsidered to be the marker of a moral obligation.
} 
(assistance, awareness) and 3 (mentioning plant species and cultural strategies such as rotation, diversification), and took shape in a vocabulary that retraced farmers' daily lives and the knowledge acquired from their personal experiences.

Figure 4 - Recomposition of the Communicative Process

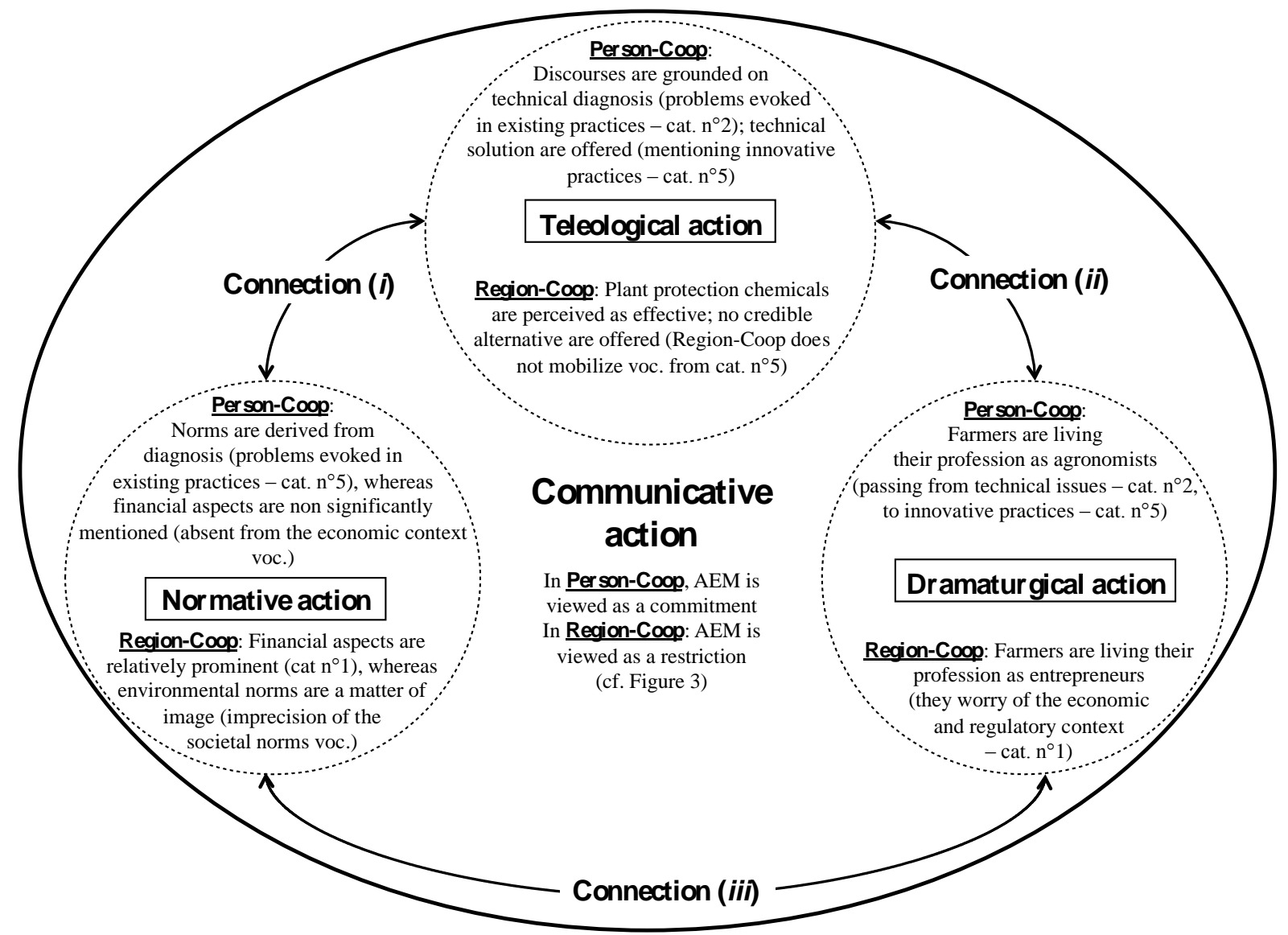

Note. This diagram shows the breakdown of the various forms of practical action (teleological, normative, and dramaturgical) and how they were transcended by communicative action when implementing the regional AEM. We listed the top five words and the grammatical category most significantly associated with each class. Production techniques to be implemented refer to teleological action; environmental and economic norms refer to normative action; how farmers defined their professional identity refers to dramaturgical action. Various aspects of the framework in which this process occurs are also presented in category 4 . The mutual understanding speech process aims to make the adoption of new practices, which challenge conventional practices, compatible with current social norms (connection (i)); the ways in which farmers conceive of their profession of 'farmer' with these new farming techniques (connection (ii)); and their perception of the farming profession with social norms that they adhere to (connection (iii)).

Figure 4 summarizes the way in which the three models of action (teleological, dramaturgical, and normative) were mobilized and interconnected in the discourses of the actors from the two cooperatives. Within Region-Coop, the communicative process did not always allow for questioning the validity of technical knowledge in terms of sustainable development norms. Instead, intercommunication seems to have reinforced the validity of economic norms and the forms of organization currently practiced on farms. Two types of discourse were, in fact, mobilized at the same time without really encouraging a change in ways of thinking and acting in farming: one, centered on the objective world, suggested more sustainable farming techniques (weederharrow, grass strip, see Figure 3a); the other 
mobilized the social world by advancing principles of general justification. In a more or less explicit way, actors mutually sought to convince each other that continuing with their intensive agriculture practices based on chemicals was irreconcilable with improving natural resource management. Moreover, the agricultural model they invoked was that of reasoned agriculture (reasoned- see Figure 3a). This model does not really break with the productivist paradigm initiated in France in the 1960s,${ }^{17}$ nor with the normative foundations on which that paradigm was based, i.e. that farming's primary responsibility to society is to ensure the nation's food self-sufficiency.At the same time, this process led actors to confirm the overall validity of the knowledge on which their professional expertise as farmers was based (conventional methods for growing and crop rotation). In the end, reassured by remaining within their certitudes, these farmers were not encouraged to update the technical knowledge guiding their strategic choices, nor to reconsider the social norms they called on to legitimate their actions, nor to enlarge their range of lived experience. In this case, then, the power of intercommunication to trigger learning remained limited.

The path adopted by Person-Coop using personalized advisors was considerably different. Because of their position, ${ }^{18}$ the personalized advisors were more easily able to free themselves from current practices. During discussions, by raising contradictions about the 'truth' of certain practices, they were able to create the conditions for learning for the farmers. For example, the advisors referred explicitly to certain techniques used in organic farming and encouraged farmers to change their method of crop rotation. ${ }^{19}$ In particular, the advisors relied on what they had learned from the experiences of the farmers that they counsel. The results of those experiences could thus be disseminated, through them, to the entire group. For these actors, changing practices were legitimized by the new social responsibilities that agriculture must now take on. Moreover, reflecting on changes in practices (encouraged by personalized advisors) fueled a discussion on the redefinition of a farmer's professional skills (reconsidering methods of economic calculation, thinking about agronomic choices at the level of the parcel and no longer at the scale of the whole farm, etc.) Thus, it is not surprising that farmers in the AEM project perceived the personalized advisors as actors of change at the heart of their farms. Thus, these advisors were better able to encourage farmers to take social and environmental concerns into consideration than the territorial advisors in the Region-Coop.

In the end, the results show that changing farming practices towards using fewer chemicals was facilitated when the communicative process articulated the three models of action described by Habermas as a coherent whole. The commitment to changing techniques appears even higher because actors worked collectively on changing the legitimizing norms for action and on redefining the knowledge that served as the basis for professional expertise at the same time.

\section{Conclusion}

\footnotetext{
${ }^{17}$ In France, the concept of 'reasoned' agriculture wasintroducedat the beginning of the 1980s by agriculture professionals to respond to growingcriticism of intensive agriculture. The creators of this concept did not seek to challenge the foundations of the productivist, intensive agriculture model; rathertheysought to limititsmostcriticizedexcesses, in particularregarding the quanity of chemicalsused. ${ }^{18}$ Contrarily to the regionaladvisors, the personalisedadvisorswere not responsible for providingtechnical-commercial advice to farmers. In otherwords, selling the chemicalsoffered by the cooperativewas not one of their jobs.

${ }^{19}$ The reference model implied by this communicative strategyisthat of organicfarming (organic, see Figure 3b).
} 
Using lexicometric methods (ALCESTE classification and similarity analysis), discourse analysis has enabled us to uncover the ways in which, and to what extent, agricultural actors were driven to redefine the context of their work. Farmers' and advisors' utterances, analyzed as part of delayed-response dialogue and debate, were collected in semi-structured interviews and enabled us to retrace uninterrupted verbal communication. This analysis revealed the way in which the communicative process, spread out over time, supported collective learning and thus supported change in a social group, here farmers and advisors, who are facing a crisis in their belief system that current legislation has called into question. This, in turn, enabled us to examine in greater detail the conditions in which interactive communication helped change a group of people's reasons for acting as part of public policy and institutional change.

Contrary to other studies in deliberative ecological economics, the approach used here does not fall within that of deliberative democracy. The deliberative processes analyzed here differ in two ways: (i) intercommunication does not occur face-to-face but at a distance in space and time; and (ii) deliberation is not limited to a single moment of collective decision-making, but is understood as a pragmatic, uninterrupted process in which decisions and discussions constantly influence each other. Thus, this kind of deliberation, which we have termed 'deliberation at a distance' following Bakhtin, is not used in order to promote the seeking of an agreement among multiple actors about the environmental values to be mobilized as shared principles of action. Rather, 'deliberation at a distance' is above all used because of its capacity to promote productive collaboration that integrates new environmental practices among actors in the business world. These innovations enable business people to incorporate new social responsibilities into their action choices, while at the same time preserving the economic viability of their business. In this view, the power of deliberation to moralize preferences is connected with its capacity to stimulate collective elaboration of technical solutions to environmental problems. Thus, as a vector of change in practices, deliberation created conditions that fostered business actors' interiorizing of new moral obligations, because it enabled the pursuit of a company's financial goals and the pursuit of the general interest to be better reconciled.

In this perspective, our case study shows that reaching the environmental goals targeted by the AEM regulatory program is facilitated when the communicative process functions: (i) it connects objective knowledge and normative knowledge, since updating the former promotes the updating of the latter; and (ii) it redefines the profession of farming in coherence with the system of norms being promoted. Supported by group deliberation and the exchange of arguments, the learning process therefore helps disseminate new technical knowledge, enlarge the range of individual experiences, and in the end, change the normative frameworks for action. Moreover, French public agencies, conscious of the role of collective action in these learning processes, are re-thinking the framework for implementing these incentive programs. One of the goals of these programs is to foster cooperation among actors through co-constructing knowledge at the ground level and then moving up to regional development, in a bottom-up process. In the French case, the terms and conditions for implementing the new European Agri-environment-climate Measures have been designed in this way.

With this goal in mind, and to pursue this research further, we believe it is important to include other actors in analyzing communicative processes, in particular people from public or para-public institutions (such as local authorities, local branches of the national government, and water agencies) as well as from agronomic research, agricultural technical institutes, environmental associations, etc. These people can contribute to a variety of knowledge and perspectives on managing local, public environmental goods and services 
(water, biodiversity, landscapes, etc.). Broadening the scope of this study is timely at a moment when certain farmers' cooperatives, which have experience in the agro-ecological transition, are in the process of re-conceptualizing the farming profession. For that purpose, they have begun to create partnerships with institutional actors. In this context, interactive deliberation between these various groups would provide precious information about the kinds of partnerships that could be created, and the roles they could play in helping economic actors to integrate sustainable development norms. Furthermore, comparing results from multiple collaborative programs would inform public actors about which organizational and institutional actions best foster new kinds of agriculture that are both economically and environmentally effective.

\section{Acknowledgments}

This paper has benefitedfromfinancial by the French Ministry of SustainableDevelopment in the framework of the «Eaux \& Territoires » Research Program (2011-2014). We would like to thank the referees for their insightful comments that helped improve the paper. We also are grateful to Cynthia J. Johnson who translated this text into English. 


\section{Bibliography}

Bakhtin, M.M.,1986. Speech genres and other late essays. [Transl. V.W. McGee; ed. C.

Emerson \& M. Holquist.] University of Texas Press.

Bromley, D.W., Päävola, J., 2002. Economics, ethics, and environmental policy: contested choices. Blackwell, Oxford.

Commons, J.R., 1934. Institutional economics. Its place in political economy.Transaction Publishers (1990), 2 vol., New Brunswick and London.

Degenne, A., Vergès, P., 1973. Introduction à l'analyse de similitude.Revue française de sociologie $14,471-511$.

Dietz, T., Stern, P.C., Dan, A., 2009. How deliberation affects stated willingness to pay for mitigation of carbon dioxide emissions: An experiment. Land Economics 85, 329-347.

Douguet, J.-M., O'Connor, M., van der Sluijs, J.P., 2007. Uncertainty assessment in a deliberative perspective, in: Pereira Guimaraes, A., Funtowicz, S.O. (Eds.), Science for policy: Opportunities and challenges. Oxford University Press, India.

Douai, A., 2009. Value theory in ecological economics: the contribution of a political economy of wealth. Environmental Values 18, 257-284.

European Commission, 2013. Overview of CAP Reform 2014-2020, Agricultural Policy Perspectives Brief.

Habermas, J., 1976. Communication and the evolution of society. Toronto, Beacon Press (translation, 1979).

Habermas, J., 1981. The theory of communicative action. Beacon Press (Translation, 1984 for vol. 1; 1987 for vol. 2), Boston.

Habermas, J., 1983. Moral consciousness and communicative action. The MIT Press (Translation, 1990), Cambridge, MA.

Habermas, J., 1991. Justification and application: Remarks on discourse ethics. The MIT Press (Translation, 1993), Cambridge, MA and London, England.

Harris, Z.S., Dubois-Charlier, F., 1969. L'analyse du discours. Langages 4, 8-45.

Hartman, L.P, Rubin, R.S. and Dhanda, KK., 2007. The Communication of Corporate Social Responsibility: United States and European Union Multinational Corporations. Journal of Business Ethics 74, 373-389.

Hodgson, G.M., 2012. From utilitarianism to evolution in ecological economics in: Gerber, J.-F., Steppacher, R. (Eds.), Towards an integrated paradigm in heterodox economics. Alternative approaches to the current eco-social crises. Palgrave Macmillan, Basingstoke, Hampshire, pp. 147-163.

Horlings, L.G., Marsden, T.K., 2011. Towards the real green revolution? Exploring the conceptual dimensions of a new ecological modernisation of agriculture that could 'feed the world'. Global Environmental Change 21, 441-452.

Howarth, R.B., Wilson, M.A., 2006. A theoretical approach to deliberative valuation: Aggregation by mutual consent. Land Economics 82, 1-16.

Koohafkan, P., Altieri, M.A., Holt-Gimenez, E., 2012. Green Agriculture: foundations for biodiverse, resilient and productive agricultural systems. International Journal of Agricultural Sustainability 10, 61-75.

Lebart, L., Salem, A., Berry, L., 1994. Exploring textual data. Kluwer Academic Publisher (English translation, 1998), Dordrecht, Boston. 
Lo, A.Y., 2013. Agreeing to pay under value disagreement: Reconceptualizing preference transformation in terms of pluralism with evidence from small-group deliberations on climate change. Ecological Economics 87, 84-94.

Lo, A.Y., Spash, C. L., 2013. Deliberative Monetary Valuation : in Search of a Democratic and Value Plural Approach to Environmental Policy. Journal of Economic Surveys Vol. 27, No. 4, pp. 768-789.

Marchand, P., Ratinaud, P., 2012. L'analyse de similitude appliquée aux corpus textuels : les primairessocialistes pour l'électionprésidentiellefrançaise (septembre-octobre 2011). Lexicometrica, 11ème journéesinternationalesd'analysestatistique des donnéestextuelles (JADT), http://lexicometrica.univ-paris3.fr/.

Martinez-Alier, J., Munda, G., O’Neill, J., 1998. Weak comparability of values as a foundation for ecological economics.Ecological Economics 26, 277-286.

Meppem, T., Bourke, S., 1999. Different ways of knowing: a communicative turn toward sustainability. Ecological Economics 30, 389-404.

Munda, G., 2008.Social multi-criteria evaluation for a sustainable economy.Springer, Heidelberg, New York.

Norgaard, R.B., 2004. Learning and knowing collectively.Ecological Economics 49, 231241.

Norgaard, R.B., 2007. Deliberative economics. Ecological Economics 63, 375-382.

O'Hara, S.U., 1996. Discursive ethics in ecosystems valuation and environmental policy.Ecological Economics 16, 95-107.

O'Neill, J., 1997. Value Pluralism, Incommensurability and Institutions. In Valuing Nature?, ed. J. Foster, Routledge.

O’Neill, J., Spash, C.L., 2000. Appendix: Policy Research Brief Conceptions of Value in Environmental Decision-Making. Environmental Values 9:521-36.

O’Neill, J., 2011. The overshadowing of needs, in: Rauschmeyer, F., Omann, I., Frühmann, J. (Eds.), Sustainable development. Capabilities, needs, and well-being. Routledge, London, 2542.

OECD, 2013.Compendium of Agri-environmental indicators.OEDCiLibrary.

Pies, I., Hielscher, S. and Beckmann, M., 2009.The Changing Role of Business in Global Society.Business Ethics Quarterly 19, 375-401.

Ratinaud, P., Dejean, S., 2009. IRaMuTeQ :implémentation de la méthode ALCESTE d'analyse de textedans un logiciellibre, ModélisationAppliquée aux Sciences Humaines et Sociales (MASHS2009), Toulouse - Le Mirail.

Ratinaud, P., Marchand, P., 2012. Application de la méthode ALCESTE à de "gros" corpus et stabilité des "mondeslexicaux"?:analyse du "CableGate" avec IRaMuTeQ. Actes des 11eme Journéesinternationalesd'Analysestatistique des DonnéesTextuelles (JADT 2012), Liège, Belgium, 835-844.

Reinert, M., 1983.Uneméthode de classification descendantehiérarchique : application à l'analyselexicale par contexte. Les cahiers de l'analyse des données 8, 187-198.

Reinert, M., 1993. Les "mondeslexicaux" etleur "logique" à travers l'analysestatistique d'un corpus de récits de cauchemars. LangageetSociété 66, 5-39. 
Rémy, J., Brives, H., Lémery, B., 2006. Conseiller en agriculture.Educagri, INRA Editions, Dijon, Paris.

Sen, A.K., 1977. Rational fools: A critique of the behavioral foundations of economic theory. Philosophy \& Public Affairs 6, 317-344.

Sen, A.K., 2002. Rationality and Freedom. Harvard University Press, Cambridge and London.

Sen, A.K., 2009. The Idea of Justice, Harvard University Press \& London: Allen Lane.

Spash, C.L., 2008. Deliberative monetary valuation and the evidence for a new value theory. Land Economics 84, 469-488.

Vatn, A., 2005.Institutions and the environment. Edward Elgar, Cheltenham, UK, and Northampton,

Vatn, A., 2009.An institutional analysis of methods for environmental appraisal.Ecological Economics 68, 2207-2215.

Voloshinov, V. N., 1986. Marxism and the Philosophy of Language . Cambridge :Harvard University Press.

Wilson, M.A., Howarth, R.B., 2002. Discourse-based valuation of ecosystem services: Establishing fair outcomes through group deliberation. Ecological Economics 41, 431-443.

Zografos, C., Howarth, R.B., 2008. Deliberative ecological economics. Oxford University Press, India.

\section{Appendix. Methodological Note}

The statistical analyses presented in this paper all proceed from the construction of a contingency table, enabling us to count the presence/absence of token-words in textual segments. Token-words - defined as an interrupted row of signs (letters or numbers) - used in the interviews are placed in rows. Segments of texts, or utterances in the words of Habermas - defined as a given number of words (in our case, 40) - are placed in columns. The table then displays the number of times a given word is used in a given segment of text.

The ALCESTE method of classification generates a descending hierarchical classification of a text understood as a single semantic unit. An algorithm first determines a two-class grouping that is the most different in terms of word occurrences (step 1), and then successively subdivides the bigger groups in two different subgroups (i.e. a group that contains the words not contained in the other sub-group - step 2). The algorithm stops when the two subgroups obtained from the division of the last biggest group are considered as significantly different in terms of the presence/absence of token-words (step 3). A chi-square test is then calculated in the aggregated table for each token-word in order to assess the significance of the association between a token-word and a semantic class (a chi-squared value of 3.84 corresponds to a probability of $0.05 \%$ that the association of a word to a certain category occurred randomly). It is important to note that ALCESTE classifies contexts and not token-words. Text segments are regrouped in classes: class 1 contains the token-words present in the text segments I and ii; class 4 those in iii, iv, v, and vi; class 5 those in vii and viii; and class 3 those in ix and $\mathrm{x}$. Variables are reintroduced in the classification with an associated chi-square test. 


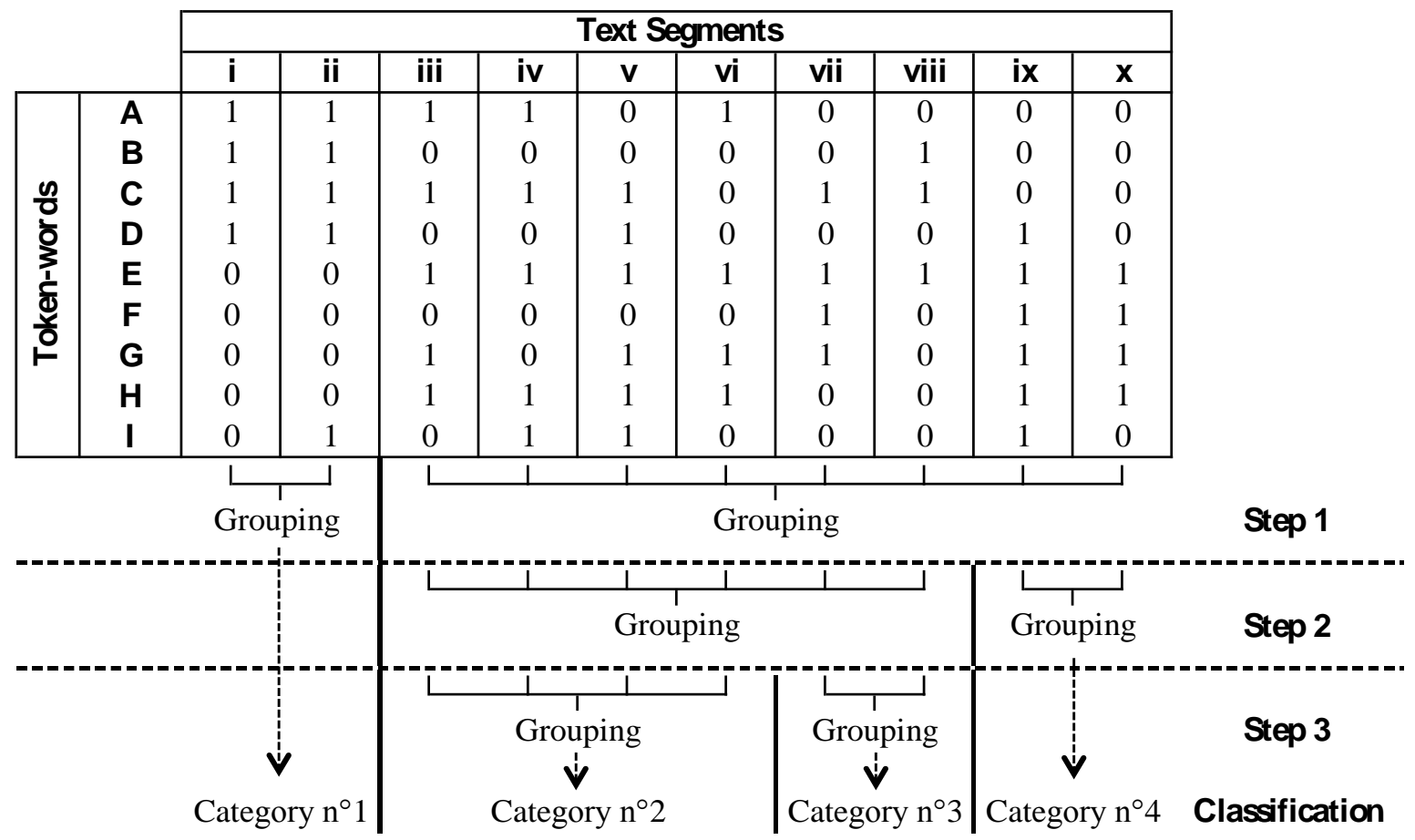

The similarity analysis studies the overall relationship between words used in the same context. By breaking down the contingency tables from the ALCESTE classification, the similarity analysis builds a tree representing the network of the words frequently used together in the same context, that is to say in the same text segments. The thickness of the line between two words represents how often those two words are used together. The similarity analysis only keeps the strongest connections by building a "connected graph without circling" (Degenne and Vergès, 1973, p.473): for each triad of words, the weakest frequency of co-occurrence is eliminated. For a triad composed of words $\mathrm{A}, \mathrm{C}$ and $\mathrm{E}$, only the two relationships $\mathrm{AC}$ ( $\mathrm{A}$ and $\mathrm{C}$ are jointly mentioned in the text segments i, ii, iii, and iv) and $\mathrm{CE}$ ( $\mathrm{C}$ and $\mathrm{E}$ are jointly mentioned in the text segments iii, iv, $\mathrm{v}$, vii, and viii) have been kept (graph I). When we add the word G, the CG relationship is excluded from the CEG triad (C and G only co-occur in text segments iii, v, and vii) and the relation AG (text segments iii and vi) is excluded from the AEG triad (graph II). Finally, the connected graph without circling is given in graph III.

I - Elimination of the weakest relationship for the triadic ACE

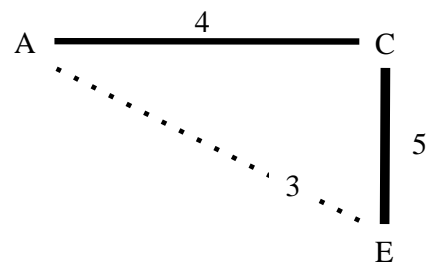

II - Elimination of the weakest relationship for all the triadic relationships

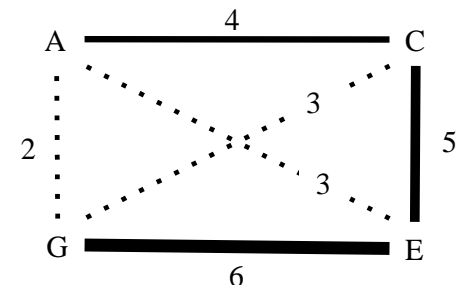

III - Construction of the "connected graph without circling"

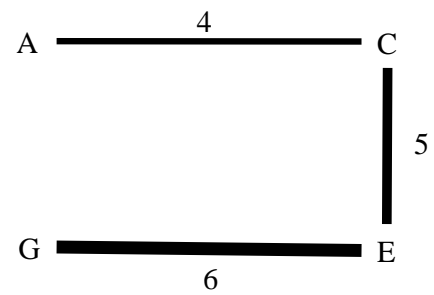

